\title{
Exterior features and productivity of the Kazakh fine-wool breed of sheep and its crossbreeds with meat breeds
}

\author{
Narzhan Zhumadillayev ${ }^{1}$, Yusupzhan Yuldashbaev ${ }^{2, *}$, Amanbai Karynbaev ${ }^{3}$, Akmal \\ Khudaiberdiev $^{2}$, and Beslan Efendiev ${ }^{4}$ \\ ${ }^{1}$ LLP "Kazakh Research Institute of Animal Husbandry and Forage Production", branch of the \\ "Research Institute of Sheep Farming named after K. U. Medeubekov", Zhibek Zholy 15, 040622 \\ Mynbayevo, Kazakhstan \\ ${ }^{2}$ Russian State Agrarian University of the Moscow Agricultural Academy named after K. A. \\ Timiryazev, 49, Timiryazevskaya St., 127550 Moscow, Russia \\ ${ }^{3}$ Non-profit Joint Stock Company "National Agrarian Scientific and Educational Center", \\ Kurgaldzhinskoe highway 4a, 010000 Nur-Sultan, Republic of Kazakhstan \\ ${ }^{4}$ Kabardino-Balkarian State Agricultural University named after V.I. V.M. Kokov, Lenin Avenue, 1V, \\ 360030 Nalchik, Russia
}

\begin{abstract}
The article presents the dynamics of changes in live weight for a year, measurements, body build indices and productivity of one-year-old pure-bred Kazakh fine-wool female lambs and crossbreeds of different bloods with German meat merino, when creating a fine-wool meat sheep breed in the south-east of Kazakhstan - "Etti merino". The resulting crossbred offspring are characterized as large animals, with a high live weight and good meat forms.
\end{abstract}

\section{Introduction}

Sheep breeding is a traditional, economically important, but also socially significant industry for Kazakhstan. Earlier, the economy of sheep breeding in Kazakhstan was based on wool production, and now there is an increased demand for mutton, especially lamb and young mutton, as a result of which it has become in demand in many countries of the world. It is known that lamb contains 2.5-4.3 times less cholesterol than beef and pork, and due to the fact that animals are kept on pasture all year round, sheep meat corresponds to environmentally friendly products $[1,2,3] \ldots$

Currently, the most high-quality and competitive meat products can be provided by specialized meat and meat-wool breeds, which are distinguished by high meat productivity, are distinguished by such biological characteristics as early maturity, intensive growth, economical transformation of feed into products $[4,5,6,7,8,9,10]$.

In this direction, an urgent problem is the creation of domestic meat breeds of sheep, by crossing local queens with rams-producers of specialized meat breeds. So in Kazakhstan in 2001 in the RESEARCH INSTITUTE OF SHEEP-BREEDINGnamed K.U. Medeubekov, a

\footnotetext{
* Corresponding author: zoo@rgau-msha.ru
} 
branch of Kazakh Research Institute of Animal Husbandry and Fodder Production LLP, work has begun on the creation of a highly productive meat fine-wool breed "etti merino"(meat merino) for export. The first step on this path was the use of sheep-breeding merinofleischschaf (MFS) of German meat merino with an array of queens of the Kazakh fine-wool breed (KFW).

Research on crossing of Kazakh fine-wooled queens with rams of German meat merino in SPK "Plemzavod Almaty" Talgar region and PK named after Eskeldy (now KH "Sariev S.M.) Eskeldinsky district of Almaty region indicates that the live weight of the offspring increases by $10-15.0 \%$, the fertility of queens increases by $15-20 \%$. When slaughtering rams at $4^{x}$ months of age, the carcasses have a mass of $19.0-20.0 \mathrm{~kg}$. The average daily gain of lambs during the suckling period is 290-300 grams.

Purpose of work. Creation in the southeast of Kazakhstan of a highly productive meat fine-wool breed of sheep - "Etti Merino", which combines high meat productivity and early maturity, as well as the ability to produce high-quality merino wool at the level of world analogues. Due to the high economic efficiency, the sheep of the new breed are in great demand in the farms of the Republic.

\section{Methodology}

The first stage of work is the creation in the 80s of the last century of the Sarybulak intrabreed type of Kazakh fine-wool sheep, large fine-wool sheep with a high live weight, wool of 60-64 quality and a high shear, obtained as a result of crossing of Kazakh fine-wool queens with rams of the Polvars breed. At the second stage, the selection work was aimed at increasing muscle mass, slaughter yield, the severity of meat forms and indicators of early maturity. For this purpose, in 2002, rams-producers of German meat merino were used on the uterus of the Sarybulak intra-breed type.

\section{Results}

As a result of the crosses, the live weight and its growth were studied in crossbred female lambs MFS of various types of blood and purebred KFW, from birth to one year of age (Table. 1)

From the data in the table it can be seen that from birth to beating the greatest average daily gains in live weight in female lamb $3 / 4$ bloods according to merinofleischschaf and from breeding "inter se" $1 / 2$ MFS KFW (288 and 276 grams, respectively) or more by 23-51 and 11-39 grams in comparison with other peers. In the period from the beating from mothers to the age of one year, the difference in the increase in live weight is somewhat preserved in half-bred animals (the average daily gain is 7-10 grams more) and in general, from birth to one year of age, the difference is within 16-15 grams.

From the data in the table it can be seen that from birth to beating, the greatest average daily gains in live weight in female lamb $3 / 4$ bloods according to merinofleischschaf and from breeding "inter se" $1 / 2$ MFS KFW (288 and 276 grams, respectively) or more by 23-51 and 11-39 grams in comparison with others. In the period from the beating from mothers to the age of one year, the difference in the increase in live weight is somewhat preserved in half-bred animals (the average daily gain is 7-10 grams more) and in general, from birth to one year of age, the difference is within 16-15 grams. 
Table 1. Live weight and its growth in one-year-old female lambs of the Kazakh fine-wool breed and crossbreeds of different proportions of blood.

\begin{tabular}{|c|c|c|c|c|c|c|c|c|c|c|}
\hline \multirow{3}{*}{$\begin{array}{c}\text { Share of } \\
\text { blood }\end{array}$} & \multirow{3}{*}{$\begin{array}{c}\text { Qty } \\
\text { (head) }\end{array}$} & \multirow{2}{*}{\multicolumn{3}{|c|}{ Live weight (kg) }} & \multicolumn{6}{|c|}{ Live weight gain } \\
\hline & & & & & \multicolumn{2}{|c|}{ suckling period } & \multicolumn{2}{|c|}{$\begin{array}{c}\text { from } 4 \text { months } \\
\text { up to a year }\end{array}$} & \multicolumn{2}{|c|}{$\begin{array}{c}\text { from birth } \\
\text { up to a year }\end{array}$} \\
\hline & & $\begin{array}{c}\text { at } \\
\text { birth }\end{array}$ & $\begin{array}{c}4 \\
\text { months }\end{array}$ & 1 year & $\begin{array}{c}\text { total } \\
(\mathrm{kg})\end{array}$ & $\begin{array}{c}\text { middle } \\
\text { daily (g) }\end{array}$ & $\begin{array}{l}\text { total } \\
(\mathrm{kg})\end{array}$ & \begin{tabular}{|c}
$\begin{array}{c}\text { middle } \\
\text { daily } \\
(\mathrm{g})\end{array}$ \\
\end{tabular} & $\begin{array}{c}\text { total } \\
(\mathrm{kg})\end{array}$ & $\begin{array}{c}\text { middle } \\
\text { daily (g) }\end{array}$ \\
\hline $\begin{array}{c}3 / 4 \\
\text { MFSKFW }\end{array}$ & 71 & $\begin{array}{c}4.3 \pm \\
0.08\end{array}$ & $\begin{array}{c}34.6 \pm \\
0.41\end{array}$ & $\begin{array}{l}51.4 \pm \\
0.45\end{array}$ & 30.3 & 288 & 16.8 & 64 & 47.1 & 129 \\
\hline $\begin{array}{c}1 / 2 \\
\text { MFSKFW } \\
\text { "inter se" }\end{array}$ & 86 & $\begin{array}{l}4.1 \pm \\
0.16\end{array}$ & $\begin{array}{c}33.2 \pm \\
0.47\end{array}$ & $\begin{array}{c}50.9 \pm \\
0.41\end{array}$ & 29.1 & 276 & 17.7 & 68 & 46.8 & 128 \\
\hline $\begin{array}{c}1 / 2 \\
\text { MFSKFW }\end{array}$ & 104 & $\begin{array}{l}4.0 \pm \\
0.07\end{array}$ & $\begin{array}{c}31.9 \pm \\
0.45\end{array}$ & $\begin{array}{c}50.6 \pm \\
0.48\end{array}$ & 27.9 & 265 & 18.7 & 71 & 46.6 & 127 \\
\hline $\begin{array}{c}1 / 4 \\
\text { MFSKFW }\end{array}$ & 96 & $\begin{array}{l}4.0 \pm \\
0.11\end{array}$ & $\begin{array}{c}29.9 \pm \\
0.42 \\
\end{array}$ & $\begin{array}{c}45.1 \pm \\
0.52 \\
\end{array}$ & 25.9 & 247 & 15.2 & 58 & 41.1 & 113 \\
\hline KFW & 93 & $\begin{array}{l}3.8 \pm \\
0.11\end{array}$ & $\begin{array}{c}28.7 \pm \\
0.43 \\
\end{array}$ & $\begin{array}{c}44.8 \pm \\
0.38 \\
\end{array}$ & 24.9 & 237 & 16.1 & 61 & 41.0 & 112 \\
\hline
\end{tabular}

The main indicator of the growth and development of animals, which determines the meat qualities of young animals, is its physique. The exterior is one of the main indicators of the animal's adaptability to certain conditions.

In this regard, exterior features were studied in the experimental young animals, for which 9 body measurements were taken from 20 female lambs of each group (Table. 2)

Table 2. Measurements of one-year-old female lambs of the Kazakh fine-wool breed and hybrids of different proportions of blood.

\begin{tabular}{|c|c|c|c|c|c|}
\hline \multirow{2}{*}{ Indicators } & \multicolumn{5}{|c|}{ Groups } \\
\cline { 2 - 6 } & $\begin{array}{c}\mathbf{3} / 4 \\
\text { MFSKFW }\end{array}$ & $\begin{array}{c}1 / 2 \\
\text { MFSKFW } \\
\text { "inter se" }\end{array}$ & $\begin{array}{c}1 / 2 \\
\text { MFSKFW }\end{array}$ & $\begin{array}{c}1 / 4 \\
\text { MFSKFW }\end{array}$ & \multirow{2}{*}{ KFW } \\
\hline Quantity, head & 20 & 20 & 20 & 20 & 20 \\
\hline $\begin{array}{c}\text { Height at the } \\
\text { shoulder }\end{array}$ & $65.2 \pm 0.35$ & $64.4 \pm 0.20$ & $60.9 \pm 0.34$ & $59.9 \pm 0.31$ & $56.3 \pm 0.26$ \\
\hline Height at hips & $66.7 \pm 0.40$ & $64.5 \pm 0.33$ & $61.3 \pm 0.47$ & $60.9 \pm 0.32$ & $56.3 \pm 0.19$ \\
\hline Diagonal body length & $67.6 \pm 0.40$ & $66.2 \pm 0.41$ & $62.1 \pm 0.36$ & $60.8 \pm 0.51$ & $56.2 \pm 0.41$ \\
\hline Chest depth & $36.3 \pm 0.24$ & $36.2 \pm 0.28$ & $35.8 \pm 0.28$ & $34.8 \pm 0.21$ & $31.7 \pm 0.31$ \\
\hline Chest width & $32.2 \pm 0.22$ & $31.5 \pm 0.31$ & $31.0 \pm 0.20$ & $29.4 \pm 0.31$ & $26.7 \pm 0.30$ \\
\hline Chest girth & $135.0 \pm 0.9$ & $133.1 \pm 0.8$ & $124.0 \pm 0.8$ & $121.9 \pm 0.8$ & $113.6 \pm 0.6$ \\
\hline Width in bricks & $20.0 \pm 0.35$ & $19.5 \pm 0.15$ & $19.0 \pm 0.37$ & $18.7 \pm 0.16$ & $17.6 \pm 0.23$ \\
\hline Half grip of the rear & $68.5 \pm 0.49$ & $67.5 \pm 0.31$ & $64.0 \pm 0.48$ & $62.2 \pm 0.67$ & $58.4 \pm 0.44$ \\
\hline Metacarpal girth & $10.1 \pm 0.05$ & $10.1 \pm 0.06$ & $10.0 \pm 0.07$ & $9.7 \pm 0.03$ & $9.5 \pm 0.08$ \\
\hline
\end{tabular}

In terms of height at the withers, the highest indicators were found in the female lambs of genotypes $3 / 4,1 / 2$ "inter se", $1 / 2$ MFSKFW. At the same time, higher indicators at the withers were observed in hybrids of $3 / 4$ blood, which exceeded their contemporaries - by $0.8 ; 4.3 ; 5.3 ; 8.9 \mathrm{~cm}$ or $1.3 ; 6.5 ; 8.1 ; 13.6 \%$. The same pattern was found for the height in the sacrum.

The oblique body length is of great importance in the development of the meat content of animals. The measurements of the oblique body length were somewhat larger in crossbred female lambs 3/4, 1/2 "inter se", 1/2, 1/4 blood $(67.6 ; 66.2 ; 62.1 ; 59.9)$ than in purebred fine-wool female lambs (56.3) ... Measurements that characterize the volumetric 
indicators of crossbred groups female lambs have been well developed: depth, width and chest girth. In particular, in terms of chest depth of female lamb $3 / 4,1 / 2$ "inter se", $1 / 2,1 / 4$ blood levels have higher absolute indices of this feature than in female lamb and exceed them, respectively, by $4.6 ; 4.5 ; 4.1 ; 3.1$ or $14.5,14.1,12.9,9.7 \%$. In terms of measurements of the width of the chest, the superiority of crossbred female lamb is $3 / 4,1 / 2$ "inter se", $1 / 2-31.9$; 31.5; 31.0. Largest chest girth possessed female lambs 3/4, 1/2 "inter se".

For evaluating animals for the development of meat content, measurements are of great importance - the width in the hips and the half-girth of the rear. So, in width in hips, the greatest indicators of this trait were noted in female lambs, $1 / 2$ "inter se", 1/2, 1/4 bloods, predominance over purebred peers, respectively, by $13.6 ; 10.8 ; 7.9 ; 6.3 \%$. The superiority in terms of half-girth of the hind is also in crossbreed female lambs $68.0 ; 67.5 ; 65.5 ; 61.9$ against 59.4 in female lambs of Kazakh fine-wool sheep.

Body measurements do not give a complete picture of the constitution of the animal as a whole. In this regard, to characterize the exterior, we used body build indices (Tab. 3), by which we judged the degree of development of the organism, the proportions of the physique and the general constitutional type of the animal.

Table 3. Body build indices in one-year-old female lambs of the Kazakh fine-wool breeds and crossbreeds of different proportions of blood.

\begin{tabular}{|c|c|c|c|c|c|}
\hline \multirow{2}{*}{ Indicators } & \multicolumn{5}{|c|}{ Groups } \\
\cline { 2 - 6 } & $\begin{array}{c}\mathbf{3} / \mathbf{4} \\
\text { MFSKFW }\end{array}$ & $\begin{array}{c}\mathbf{1} / 2 \\
\text { MFSKFW } \\
\text { "inter se" }\end{array}$ & $\begin{array}{c}1 / 2 \\
\text { MFSKFW }\end{array}$ & $\begin{array}{c}\mathbf{1} / \mathbf{4} \\
\text { MFS } \\
\text { KFW }\end{array}$ & \multirow{2}{*}{ KFW } \\
\hline Leggy & 44.3 & 43.7 & 41.2 & 41.9 & 43.7 \\
\hline Stretchiness & 103.7 & 102.7 & 101.9 & 101.5 & 99.8 \\
\hline Hip-chest & 161.0 & 161.5 & 163.2 & 157.2 & 159.6 \\
\hline Chest & 88.7 & 87.0 & 86.5 & 84.5 & 84.2 \\
\hline Blockiness & 199.7 & 201.1 & 199.6 & 200.5 & 201.6 \\
\hline Overgrow & 102.3 & 100.2 & 100.7 & 101.7 & 100.0 \\
\hline Boniness & 15.4 & 15.7 & 16.4 & 16.1 & 16.8 \\
\hline Massiveness & 207.1 & 206.6 & 203.3 & 203.5 & 201.8 \\
\hline Meat & 105.1 & 104.8 & 105.1 & 103.8 & 103.7 \\
\hline
\end{tabular}

The index of elongation characterized the crossbred female lambs as long-bodied animals with an elongated format - 3/4 - 103.7, 1/2 "inter se" - 102.7, $1 / 2-101.9,1 / 4-101.5$ versus KT-99.8.

The indices of the pelvic-thoracic and thoracic, characteristic the volumetric indicators, were higher in the female lambs received from German producers and their sons. The chest index in female lamb MFSKFW 3/4, 1/2 "inter se", 1/2, 1/4 bloods, exceeded their KFW contemporaries, respectively, by $4.5 ; 2.8 ; 2.3 ; 0.3$ or $5.3 ; 3.3 ; 2.7 ; 0.4 \%$. The indices of massiveness and meatiness characterize the development of the trunk in width According to these indices, the female lambs MFSKFW surpass the KFW purebred female lambs and characterize them as wider-bodied, with developed meat forms.

Along with the indicators of growth and development, in order to obtain a complete characterization of the offspring of purebred and crossbred female lambs breeds, we analyzed productivity data at one year of age (Table. 4)

In one-year-old female lamb, the highest indicators of live weight have three-quarterblooded and half-blooded ones from breeding "inter se" (respectively, 51.38 and $50.93 \mathrm{~kg}$ ), which exceeds pure-bred Kazakh fine-wool female lambs by 6.58-6.13 kg or 14, 7-13.7 per cent. However, for quarter-blooded MFSKFW, no noticeable differences are observed for this feature. 
In terms of the length of the wool fiber, the most "long-haired" were the crossbreeds of $1 / 2$ MFSKFW from breeding "inter se" (by $0.56 \mathrm{~cm}$ or $6.02 \%$ ). There are no significant differences between the rest of the groups according to the indicated characteristics.

A higher cut of wool is characteristic of the female lambs obtained from breeding "inter se" half-blooded MFSKFW hybrids, which surpassed the rest of the groups in this indicator by $0.3-0.17 \mathrm{~kg}$. In addition, among them there are more animals of the elite and class I (by $15-4 \%$ ) in comparison with purebred Kazakh fine-wool sheep and other crosses.

Table 4 Productivity of one-year-old female lambs of different proportions of blood.

\begin{tabular}{|c|c|c|c|c|c|}
\hline $\begin{array}{c}\text { Breed } \\
\text { bloodiness }\end{array}$ & $\mathrm{n}$ & $\begin{array}{c}\text { Live weight, } \\
\mathrm{kg}\end{array}$ & $\begin{array}{c}\text { Cut } \\
\text { wool, } \mathrm{kg}\end{array}$ & $\begin{array}{c}\text { Wool length, } \\
\mathrm{cm}\end{array}$ & $\begin{array}{c}\text { Output el } \\
+ \text { I class. } \\
\%\end{array}$ \\
\hline $3 / 4 \mathrm{MFSKFW}$ & 56 & $51.38 \pm 0.45$ & $5.06 \pm 0.07$ & $9.36 \pm 0.10$ & 72 \\
\hline $\begin{array}{c}1 / 2 \mathrm{MFSKFW} \\
\text { "inter se" }\end{array}$ & 50 & $50.93 \pm 0.41$ & $5.23 \pm 0.07$ & $9.86 \pm 0.10$ & 76 \\
\hline $1 / 2 \mathrm{MFSKFW}$ & 75 & $50.65 \pm 0.48$ & $4.98 \pm 0.05$ & $9.52 \pm 0.09$ & 68 \\
\hline $1 / 4 \mathrm{MFSKFW}$ & 46 & $45.13 \pm 0.52$ & $4.88 \pm 0.06$ & $9.36 \pm 0.10$ & 64 \\
\hline KFW & 120 & $44.80 \pm 0.33$ & $4.96 \pm 0.03$ & $9.30 \pm 0.06$ & 61 \\
\hline
\end{tabular}

\section{Conclusions}

Thus, German meat merinos have a positive effect on the indicators of meat productivity of the Kazakh fine-wool breed: they increase muscle mass, slaughter yield, the severity of meat forms and indicators of early maturity, which indicates the possibility of keeping them in the conditions of deserts and semi-deserts of Kazakhstan and are distinguished by high meat productivity.

\section{References}

1. A. I. Erokhin, E. A. Karasev, Yu. A. Yuldashbaev, Izvestiya TSKHA, 2, 126-135 (2012)

2. A. I. Erokhin, T. A. Magomadov, E. A. Karasev, Formation of meat content in sheep in postnatal ontogenesis (2010)

3. M. E. Karabaeva, Diss. Dr. Biol. Sciences (2016)

4. V. I. Kosilov, E. A. Nikonova, B. B. Traisov, Sheep, goats, woolen business, 3, 25-26 (2018)

5. Aboneev V.V., Skorykh L.N., Strategy and main directions of development of sheep and goat breeding in Russia, 45-48 (2002)

6. A. V. Derevyankin, Author's abstract. Cand. diss. (2004)

7. O.K.Gogaev, K.E. Kessaev, B.S.Kaloev, M.E. Kebekov, T.T.Tarchokov, Asian Journal of Microbiology, Biotechnology and Environmental Sciences 18(4), 1029-1038 (2016)

8. V V Aboneev, T .T .Tarchokov, S. F. Sukhanova, D. V. Aboneev, E. V. Aboneev and V. V. Marchenko, Magazine "IOP: Earth and Environmental Science», 341(1) (2019)

9. I. F. Gorlov, N. V. Shirokova, E. Y. Anisimova, M. I. Slozhenkina, Y. A. Kolosov, A. K. Natyrov, A.Y. Kolosov, N. I. Mosolova, M. A.Kolosova, T. T. Tarchokov, Journal of Applied Animal Research, 49(1) (2021)

10. M. B. Ulimbashev, V. V. Kulintsev, M. I. Selionova, R. A. Ulimbasheva, B. T. Abilov, Z. T. Alagirova, South of Russia: Ecology, Development, 13 (2018) 